\title{
TIO/SNA -123
}

\author{
NOCLEAR ROCKET OPFERTIONS
}

\section{SACRAMENTO PLANT}

RELIABILITY AND QUALITY ASSURANCE

INFORMAL PROGRESS LETTER NO. 4IA

$$
\text { FOR SECOND QUARTER, CY } 1967
$$

COVERING

JANUARY, FEBRUARY, AND MARCH 1967

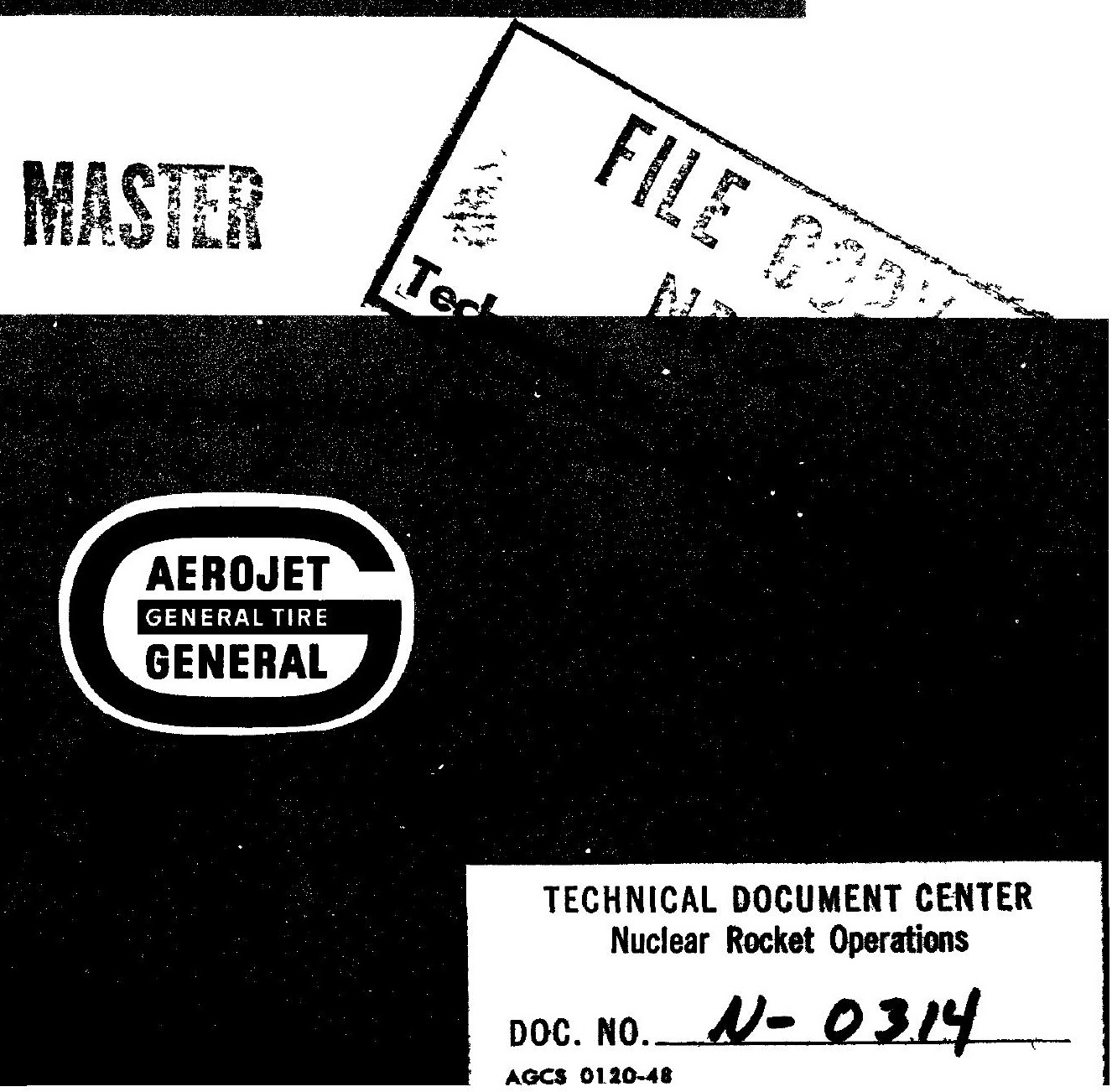




\section{DISCLAIMER}

This report was prepared as an account of work sponsored by an agency of the United States Government. Neither the United States Government nor any agency Thereof, nor any of their employees, makes any warranty, express or implied, or assumes any legal liability or responsibility for the accuracy, completeness, or usefulness of any information, apparatus, product, or process disclosed, or represents that its use would not infringe privately owned rights. Reference herein to any specific commercial product, process, or service by trade name, trademark, manufacturer, or otherwise does not necessarily constitute or imply its endorsement, recommendation, or favoring by the United States Government or any agency thereof. The views and opinions of authors expressed herein do not necessarily state or reflect those of the United States Government or any agency thereof. 


\section{DISCLAIMER}

Portions of this document may be illegible in electronic image products. Images are produced from the best available original document. 

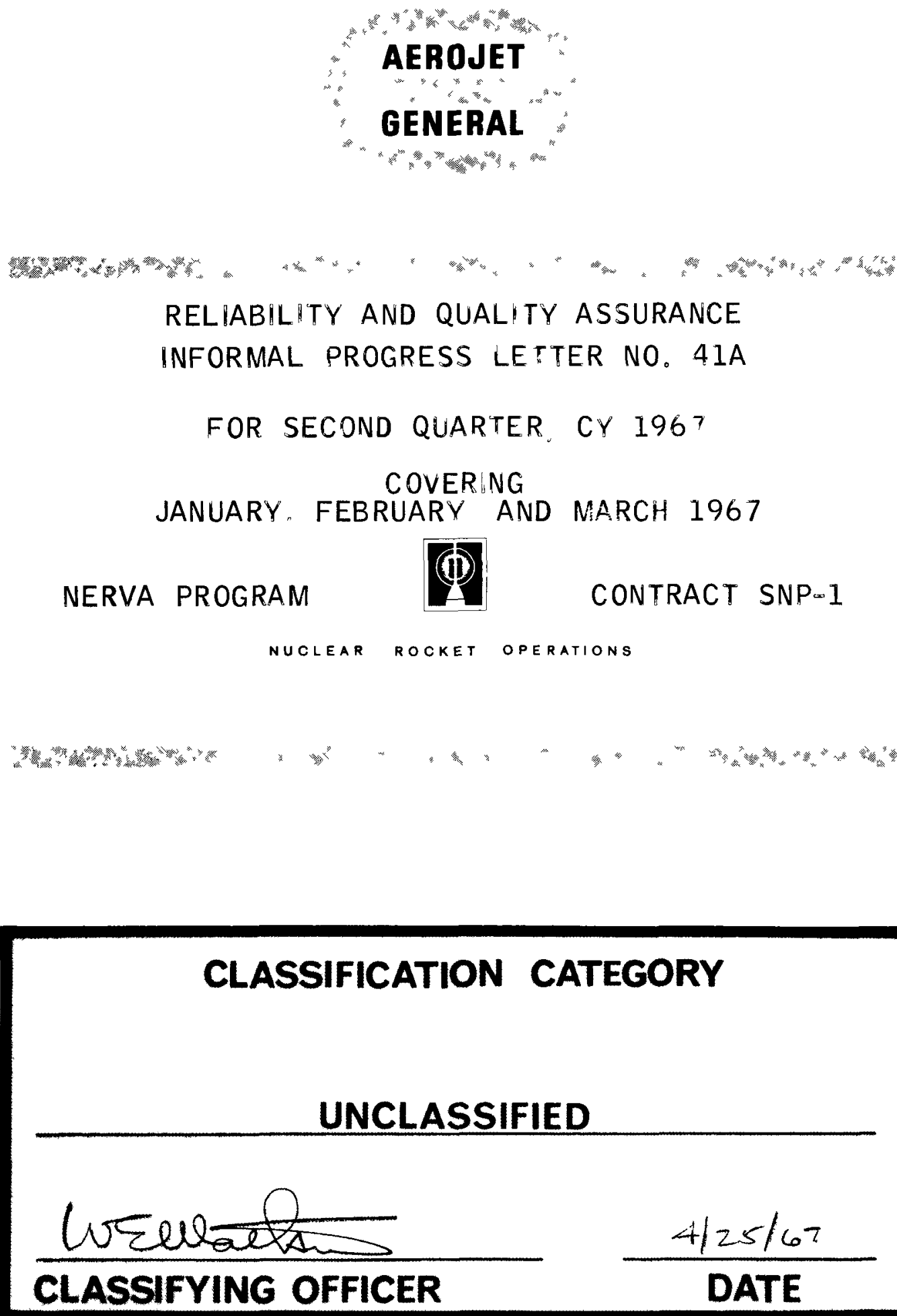
sponsored by the United States Government. Neither the United States nor the United States Energy Research and Development Administration, nor any of their employees, nor any of their contractors, subcontractors, or their employees, makes any warranty, express or implied, or assumes any legal liability or responsibility for the accuracy, completeness or usefulness of any information, apparatus, product or 
PAGE BLANK

i i 
FOREWORD

This report is in partial fulfillment of Subtask 2.6 of Contract SNP-1. The discussion covers Product Assurance activities of NRO, NTO and Quality ControlSacramento Plant, for the second quarter (January, February and March) of Contract Year 1967. 
TABLE OF CONTENTS

I. SUBCONTRACTOR AND NTO SURVEILLANCE

A. NRO Product Assurance Activities, Sacramento 1

B. Ancillary Contracts 5

C. WANL Activities 7

D. Other Activities 10

II. RELIABILITY ASSURANCE 13

A. Reliability Program Management 13

B. Reliability Engineering 13

III. QUALITY ENGINEERING 18

A. Procurement and Fabrication Control 18

B. NERVA Quality Engineering 20

IV. NRO QUALITY ASSURANCE 28

A. Systems and Procedures 28

B. Data and Documentation 30

C. Statistical Data (NERVA Hardware) 33

D. Quality Assurance Test Area 36

$\begin{array}{ll}\text { V. NTO PRODUCT ASSURANCE } & 37\end{array}$

A. General 37

B. MAD - Operations 37

C. Test Cell "C" Operations 38

D. ETS-1 Operations 39

E. Reliability $\quad 40$ 
I. SUBCONTRACTOR AND NTO SURVEILLANCE

A. NRO PRODUCT ASSURANCE ACTIVITIES, SACRAMENTO

Subcontractor purchase order review activity has been maintained by Subcontractor Control. Subcontractor Control contributed to the review comment and approval on numerous procedures, specifications and plans. During this report period, a number of purchase order packages were reviewed prior to transmittal to SNPO-C. Subcontractor Control reviewed and approved 153 Ground Support Equipment (GSE) and NERVA Exhaust System (NES) drawings.

1. Bendix Corporation, Research Laboratories Division, Southfield, Michigan, Turbine Power Control Valve Actuators (TPCVA), P.0. NP-000132 and P.0. NP-000141

Bendix Research Laboratories has completed the NP-000132 Contract to refurbish two Model NT-C2 Turbine Power Control Valve Actuators, $\mathrm{S} / \mathrm{N} 11$ and S/N 13 during this report period. Actuator S/N 13 was shipped to AGC Sacramento for continued testing. Test results in conjunction with other background information determined this actuator's non-acceptability for the $\mathrm{XECF}$ operation. Actuator S/N 11 was final tested at Bendix this report period and was found to be not acceptable due to various bearing problems in the transmission. The actuator was disassembled at Bendix Corporation, each part tagged acceptable or not acceptable and the disassembled unit sent to AGC Sacramento for disposition.

The NRO Purchase Order NP-000141 requirements for five NT-D2 actuators was again reviewed with Bendix Product Assurance personnel this report period. All long lead items are in the process of being procured and the R \& QA Plan, Factory Inspection Plan, Control Point Schedule and Shop Planning have been reviewed by NRO PAD and found acceptable. Continued close coordination with Bendix Product Assurance is being maintained and QC requirements will be initiated and followed through by Bendix and verifled by NRO Product Assurance Division. 


\section{Manned Control Car and Engine Installation Vehicle (MCC/EIV) - NRDS}

A modification design effort was completed this report period and all drawings reviewed and approved by NRO PAD. The following design modifications were completed:

(a) A load readout system for the EIV to indicate engine load and insertion force when installing the XE into ETS- 1 .

(b) A control system, including two 3-way solenoid valves mounted on the EIV, for controlling the air flow to-and-from the Turbine Exhaust Nozzle Closures.

(c) Additional Indicator Lights to show positions of the EIV Mounted Engine Dust Cover and the Engine Nozzle Closure Actuator.

(d) A control system for actuating the solenoid operated Bleed Valve mounted on the Engine Nozzle Closure.

(e) Modified engine support pads on the EIV to provide clearance for the larger brackets and longer bolts used to join the engine LTS to the Engine External Shield.

(f) A new umbilical lock mechanism to be mounted on the EIV to assure that the umbilical can be unlocked and released from the EIV in an emergency situation.

Additional design effort was expended in selecting new springs for the EIV to correct a shock transmittal problem encountered during transportation, shock and vibration testing of the MCC/EIV at NRDS. A conceptual design was completed of modifications required to enable the EIV to mate to the XE at ETS-1 with the S-2 side shield in position at the engine. 
A design review concerning the use of back-up tools,

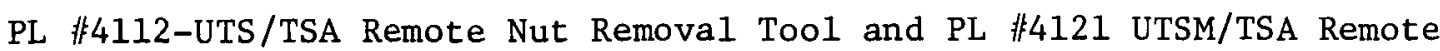
Coupling Device, by the EIV manipulators, in the event of malfunctioning of the engine to the TSA Marman Clamp actuators and/or TSA to UTS at tachment bolt actuators, was conducted. The review indicated that an EIV mounted tool rack to support the tools was not required and the design was cancelled.

Fabrication and NRO PAD acceptance of the direct viewing mirrors for the EIV were completed and the mirror assemblies shipped to NRDS for installation. The following hardware for the EIV/MCC modification has been procured and final accepted by NRO Product Assurance:

\section{(a) Load Readout System}

(b) Indicator Lights for the dust cover and nozzle closure actuator

(c) Control System for Turbine Nozzle Closures

(d) Control System for Nozzle Closure Bleed Valve

New springs were procured, installed and satisfactorily tested and accepted. Fabrication has started on the modified engine support pads to be mounted on the EIV's Lateral and Azimuth Carriage and the new designed EIV Vehicle Lock Mechanism is in the proposal/procurement stage. The hardware for modifying the UTS Positioning Head was completed and accepted and is in the process of being installed at NRDS.

\section{Post Operative Cell Material Transfer System (POCMTS) - NRDS}

The disposition and corrective action relative to the discrepancies found during the final acceptance testing at NRDS has been completed. The POCMTS End Item Report is in the final stages of completion and the End Item Review should convene early in the next report period. 
4. NRX and X Mechanical Ground Support Equipment, NRX Equipment

The design effort to modify and improve the operability and reliability of the remote .812 (13/16) Bolt Removal Tool for NRX-A6 disassembly was initiated and is being followed by NRO PAD. The design effort and NRO PAD review and acceptance were completed for minor modifications to the following:

(a) Locating wedges were modified on the Remote Cooldown Nozzle Cover to eliminate interference with Test Cell "C" Shield Impedance Ring.

(b) The Nozzle Examination Fixture was modified to eliminate interference with the Nozzle Weld Bead.

(c) The Remote Thrust Chamber/Reactor Disassembly Fixture was modified to increase the static load to 40,000 pounds. NTO is to modify the equipment and NTO Product Assurance surveillance will be initiated.

The following $\mathrm{XE}$ support equipment is being reviewed for Product Assurance compliance and acceptance at AGC Sacramento:

Nomenclature

ETS-1 Maintenance Platform

Remote Conoseal Installation Tool

UTSM Shipping Container

Pressure Vessel Flange Protector

Remote Checkout Adapter Kit

Engine Nozzle Closure

Turbine Exhaust Nozzle Closure

Remote Engine Reassembly Stand

UTS Platform (internal)

Insulating Shield Lifting Fixture
Design Status

$100 \%$

$100 \%$

$100 \%$

$100 \%$

$100 \%$

$100 \%$

$100 \%$

$100 \%$

$20 \%$

$5 \%$ 
The Engine Assembly Stand was fabricated and preliminarily checked out and shipped from AGC Sacramento to NRDS. The Engine Maintenance Platform, the UTSM Shipping Container and the Pressure Vessel Flange Protectors fabrication was completed and inspected late this report period. Fabrication of the ETS-1 Maintenance Platform is to be completed early next report period. Source acceptance of this item will be performed by NRO PAD.

\section{5. $\mathrm{NRX}$ and XE Electrical Ground Support Equipment}

The drawing packages for the Functional Valve and Leak Test Set, the Engine Electrical Test Set, the Remote Adapter Kit and the Electrical Simulator for the E-MAD XE Engine checkout equipment have been completed, reviewed, and accepted by NRO PAD during this quarter. The equipment was fabricated at AGC Nucleonics Plant in San Ramon, source accepted by NRO PAD and shipped to NRDS. Engineering coverage was provided at NTO by NRO Project and PAD for the initial operation of the equipment. Interfacing WANL equipment was connected to the Engine Test Set and operated satisfactorily in all modes. The operating and maintenance procedures are currently being prepared by NRO and when acceptable will be transmitted to NRDS. Coordination has been maintained with appropriate NRO, SNPO-C, SNPO-N, NTO, WANL, ACFI and various subcontractors to insure proper integration of support equipment activities with the NERVA Program objectives.

\section{B. ANCILLARY CONTRACTS}

\section{ETS-1 Exhaust Duct - NRDS}

The completion of the Phase I NES design demonstrations test was the most significant activity at the ETS-1 this quarter. NRO Project and PAD support was provided NTO during the testing. A special performance evaluation and review team (SPEAR) comprised of 10 members assisted NTO and the Test Review Board in data reduction and evaluation. 
During the Phase I test, the side shields were not yet available, consequently, a specially fabricated pressure vessel was used as a Temporary Engine Compartment (TEC). The Steam Generator data secured from the four tests (NEP I through NEP IV) conducted at ETS-1 indicates that during the NEP I Test, the SGS "pull-down" capability was determined without primary flow. The TEC pull-down during the single generator operation was 10.7 psia and during the two generator operation the pressure was reduced to 8.4 psia. During the NEP III, Full Chamber Test at design conditions, a chamber pressure of 550 psia was attained, coupled with a design turbine exhaust flow of $7.0 \mathrm{lb} / \mathrm{sec}$. Under these conditions, a TEC pressure of 0.8 psia was obtained. The NEP IV, Full Chamber Test at OFF Design Condition was terminated due to a malfunction of the control circuitry of the primary flow valve (PCV 449) which caused the valve to close. The primary objectives of the test were not met, but a secondary objective was obtalned in which a chamber pressure of 439 psia was attained and the TEC pressure increased rapidly from 0.5 psia to 7.4 psia with no overshoot, thus demonstrating the ability of the Steam Generator System to perform its intended function as an aerodynamic "check valve".

The joint SNPO-C/AGC/WANL Test Review Board determined that the last test (NEP IV) was of limited success and decided that if any additional test information was required, it could be obtained from Phase II testing.

Due to a restricted flow of coolant water in the lower 8 tubes of the duct secondary section, a redesign of the tube outlet is being made and will be incorporated and checked out during Phase II testing.

2. ETS-1 Engine Compartment Radiation Shield, Westinghouse Electric Corporation, Sunnyvale, California and NRDS

As indicated in previous reports, reliability is not a requirement in the SNPC-30 Contract, but deviations, waivers, nonconformances, acceptance tests and witnessing of weld mock-ups of hardware pertaining to the 
Radiation Shields Engine Compartment has continued to assure the preservation of inherent reliability.

The NRO Field Product Assurance Representative has continued surveillance of the Engine Compartment Radiation Shields at ETS-1 on a full time basis up to 18 March 1967 and as a member of the ECRS Task Force.

The lower Eutectic trough was satisfactorily tested and accepted. Radiation Side Shields S-1 and S-2 were successfully mated with the convolute seals in place.

Partial beneficial occupancy of the Engine Test Compartment was obtained on 18 March 1967, at which time the contractor agreed to leave the Site in order that the Task Force could perform the Transfer Car's reliability tests giving WEC further time to fabricate new water coolant lines and procure a new heating element for the upper Eutectic troughs, after which WEC is to return to the Site and finish the installation of above mentioned hardware. At this time a certificate of completion will be issued by SNPO-N.

\section{WANL/WAFF ACTIVITIES}

The coordination effort associated with the preparation of Failure Mode Analyses for the Technology Program continued during this reporting period. WANL continued to pursue the critical systems of Test Cell "C". The WANL FMA for the XE-1 Control Drum System, WANL-TME-1523 was reviewed.

WANL was requested to perform ETS-I FMA coverages for the following items:

Power Increase Timer

Log Count Driver

Lead Reactor Engineer Console Panel

Lead Reactor Engineer Console Panel
$937 J 845$

909E976

$928 \mathrm{~F} 717$

928 F719 


$\begin{array}{ll}\text { Lead Reactor Engineer Console Pane1 } & 928 \mathrm{~F} 721 \\ \text { Lead Reactor Engineer Console Panel } & 928 \mathrm{~F} 715 \\ \text { Lead Reactor Engineer Console Chassis } & 937 \mathrm{~J} 907 \\ \text { Assistant Test Engineer Console Panel } & 928 \mathrm{~F} 723 \\ \text { Assistant Test Engineer Console Pane1 } & 928 \mathrm{~F} 725 \\ \text { Start-up Nuclear Instrumentation } & 909 \mathrm{E} 977 * \\ \text { Linear Nuclear Instrumentation } & 909 \mathrm{E} 978 * \\ \text { Log Power Nuclear Instrumentation } & 909 \mathrm{E} 979 * \\ \text { Log Power Nuclear Instrumentation } & 909 \mathrm{E} 772 * \\ \text { ECS Reactor Subsystem } & 909 \mathrm{E} 773 \\ 24 \text { VDC Power Supply } & 936 \mathrm{~J} 157 \\ \text { Reactor Safety System Chassis } & 937 \mathrm{~J} 909 \\ \text { Temperature Average and Reject Chassis } & 936 \mathrm{~J} 154\end{array}$

*This includes the neutronic sensors.

The interface characteristics for the XE-1, XE-2, and A-6 were coordinated with WANL and NTO.

The mid-year adjustment to WANL's CY 67 Product Assurance effort was effected in coordination with WANL and SNPO-C.

A Westinghouse report covering the functions and testing of the resistivity gage to be used as a method of determining the presence and location (but not the quantity) of $X$ coating in fuel element bores for NRX and XE reactors was reviewed. This equipment, in confunction with other inspection techniques, is to be used on fuel elements starting with NRX-A6. The repeatability of this equipment is such that the equipment will repeat with the $\pm .7 \%, 98.8 \%$ of the time. Inasmuch as the drawing tolerance requirement is $2 \%$, this equipment is acceptable for the proposed intent. Since no quantity or thickness determination is made with this equipment, no statement of accuracy is required. 
Action has been initiated to develop a procedure for reviewing WANL ICD/MRL(J) interface compliance for the XE-1 reactor. To provide additional information for generating procedures, a review of these interfaces will be made and the adequacy of the coordination and documentation of discerned deviations will be made. The knowledge gained from this effort will be applied to a similar effort relative to $\mathrm{NRX}-\mathrm{A} 6$.

Interface gaging capabilities will not exist for NRX-A6 and it will be necessary to identify the characteristics to be determined, and to coordinate with Westinghouse Product Assurance in the manner in which they will verify, coordinate and document possible deviations. A comparable effort will be required for MRL(J) interfaces.

Minor rework was accomplished by Westinghouse on the leak test closure and bolts received from NTO scheduled to be used on the XE-1 reactor pressure vessel assembly. The rework of the closure itself was a minor modification to facilitate use during the leak test procedure. The rework applicable to the bolts was required because of thread damage suffered during shipment from NTO.

An effort directed at reducing the number of WANL VR's/NMDR's was continued in the area of the WANL Machine Shop. Informal discussions were held with cognizant Westinghouse management identifying what appeared to be an unacceptable condition. A sample lot of NMDR's (from the Machine Shop area) was evaluated to determine cause and corrective action requirements. Corrective action was determined and implemented with an almost immediate reduction in the number of discrepancy documents being noted.

Review of handling practices is presently underway to determine what corrective action is required to reduce the part damage during inspection, cleaning, stores and other operations. Recommendations have been made to NRO Product Assurance management regarding changes in the Westinghouse 
Product Assurance Program Plan to provide procedural capabilities for extending the effort of reducing VR's and NMDR's.

Discussions have been held relative to the NRO/SNPO concern regarding the adequacy of the beta backscatter calibration curve(s) for both WAFF and Y-12. As a result of this demonstrated concern, Westinghouse and Y-12 are now performing statistical studies to determine the most satisfactory mathematical method of presenting these calibration curve(s) and also the deviation(s) that can be expected with the several methods. It appears, on the basis of preliminary information, that deviations in the range of $10 \%$ to $20 \%$ can exist at certain data points, depending on which mathematical manipulation is used to fit the curve. This effort is continuing and should be resolved prior to the release of $\mathrm{NRX}-\mathrm{A} 6$ elements to assure the most accurate inspection information possible and provide for the most reliable final gamma determination on the completed elements.

Assembly of the XE-1 core and installation in the pressure vessel was accomplished during this period. Assembly of this unit has gone remarkably well and this may be partially attributed to the extreme care exercised in the final stages of the reactor build. Preliminary information at this time indicates no instrumentation has been lost and no instrumentation is considered "suspect".

D. OTHER ACTIVITIES

\section{Steam Generator System - NRDS}

The fabrication of new combustion chambers, S/N 880001, 880002 and 880003 at Aerojet, Sacramento was completed this report period. The combustion chambers were completely inspected, hydrostatically tested, flow calibrated and dye penetrant inspected prior to shipment to NRDS. 
The three igniters, S/N 880001, 880002 and 880003, P/N 901564-200 and injectors S/N 880001, 880002 and 880003, P/N 901543, Rev. N being fabricated at Thiokol Chemical Corporation, Reaction Motors Division, Denville, New Jersey on AGC P.0. NP-000134 were completed, source accepted at Thiokol by NRO Product Assurance Division Representative and shipped to NRDS, Jackass Flats, Nevada.

\section{Coordination with NTO}

The NTO Product Assurance Program Plan NTO-A-00.13 Revision 1, and the Test Cell "C" Quality Assurance Program Plan were prepared and reviewed jointly by NTO, WANL and NRO. These plans will be presented to SNPO-C for approval during the next quarter.

The EG\&G Quality Assurance Procedures Manual is still in various stages of preparation. A scheduled completion date has not been published.

NRO continued to provide temporary assistance to NTO Product Assurance at ETS-1, E-MAD, and TCC during this reporting period.

The NTO mid-year adjustment to $\mathrm{CY} 67$ and the preparation of the 8-year plan was coordinated with NTO, Product Assurance.

Continuing coordination has been maintained with NTO Product Assurance to obtain valid "as built" drawings, for the ETS-1 FMA preparation by NRO Facilities Engineering Department and Product Assurance Division.

\section{Coordination with SNPO-C}

During the Cleanliness Committee meeting at NRDS the chairman of the committee, J. Dutli, SNPO-C, determined that the condition of the fluid flow system of the ETS-1 warranted immediate attention from a failure mode 
analysis point of view. Mr. Dutli directed NRO-PA to prepare, not later than April, a fallure mode analysis for the ETS-1 fluid flow system.

NRO-PA participated with Program Management, NTO and SNPO-C in an evaluation of the NTO ETS-1 Thrust Ring procurement and the Thrust Ring repair, and in the preparation of a design package for a new procurement by NRO. The drawings and specifications for the procurement of a new Thrust Ring will be completely revised to assure procurement of a satisfactory ring to the current engine test requirements. 


\section{RELIABILITY ASSURANCE}

\section{A. RELIABILITY PROGRAM MANAGEMENT}

A reliability program plan was prepared for CY '68 and for the entire eight year effort according to the latest customer guidelines. These include provisions for a "Parts and Material" program according to Section 3.9 of Reliability Publication NPC 250-1 and for reliability support to the E/STS-2/3 facility design and construction.

The review, analysis and summary of the Quality Reliability Disposition Reports (QRDRs) were continued on a monthly basis. Corrective actions initiated by NRO, NTO and WANL were reviewed for adequacy; where prudent, followup action was taken to assure the effectiveness of the previously initiated corrective actions. Also, where appropriate, the failure data was applied to the ETS-1 FMA's and the planning for future site tests. Furthermore, this failure data, coupled with basic engineering analysis, provided the basis for a series of recommendations made by Reliability to the responsible organizations upon review of the following documents:

1. NTO NRX-A6-P2 Procedure

2. Final Report NRX-A5 Fission Product Plate-Out Study

3. Final Report Radio Chemical Analysis of NERVA Samples

4. FDET Memoranda for ETS-1, FEP-I, FEP-IA, FEP-IB and FEP-IIA

5. Spear Committee Reports of 26 January, 1 February and 13 February

\section{B. RELIABILITY ENGINEERING}

\section{Reliability Design Studies}

Supplementing the propulsion system reliability study reported previously, a subsystem study on the ZERO NPSP TPA was concluded 
during this report period. Reliability estimates for the positive and ZERO NPSP TPA's were generated using historical flight and ground test TPA reliability data. It was concluded that the ZERO NPSP TPA would have a slightly lower reliability (by 3 failures in 10,000) than the positive NPSP TPA. However, this lower reliability was considered an acceptable risk when compared with the advantages to the total system that would be provided by the ZERO NPSP TPA.

A preliminary study of TPCV redundancy concepts was completed, for use in forthcoming design reviews. Four schematic configurations were analyzed considering the following factors: simplicity, reliability, redesign effort, cost and weight. Weighting factors for each of these design objectives were established and combined to establish an order of preference for the four configurations.

\section{Failure Mode Analysis}

On 16 March a draft of the XE-1 FMA was issued for coordination. It contains the critical engine subsystems and components, and will be used in completing the ETS-1 FMA's. A schedule has been established for the preparation of FMA's on ETS-1 covering the most critical facility subsystems. The basis for subsystem selection was the nuclear accident potential of its failure on the test article while undergoing test. The FMA's for these priority subsystems are to be completed by July 1967.

Facility FMA efforts completed during this quarter included the following analysis and reliability improvement actions:

(a) Steam Injector reliability improvement analysis.

(b) Review of the NES Duct rellability.

(c) Coordination and direction of Assigned FMA efforts to WANL, NTO and Subcontractors. 
(d) Review of XE-1 and Nuclear Subassembly FMA's for the establishment of interfaces and coordination with the ETS-1 FMA's.

(e) Recommendation for the inclusion of an additional stop valve in acid supply system of the ETS-1 demineralized water supply.

(f) Review of the ETS-1 Shield fill and draw system FMA with recommendation for procedural changes and the incorporation of an additional relief valve.

(g) Reliability analysis of the repair of V-5001 Run Tank.

(h) Review of the report "Proposed Modifications to Diesel Engine Fuel System at ETS-1".

\section{Design Review}

An extensive analysis was made of the design review activity, including the implementation of design decision theory and systems engineering concepts. The objective of this analysis was to present a basic approach for the utilization of checklists in the NERVA design review activity. It was concluded that the goal of the design review activity should be: "To Increase the Objectivity of Design Decisions Leading to More Unified Program Objectives and Policies". Also, specific recommendations were made regarding the type of checklist to be used in the NERVA design review program.

The NERVA Engine PSOV design criteria and a preliminary PSOV drawing were reviewed, and a summary of reliability considerations was submitted to Design Engineering in preparation for a preliminary design review meeting. This meeting was held at the end of the quarter and was attended by representatives from the cognizant technical and operational groups. Design Engineering presented the PSOV program schedule. Principal valve features were reviewed relative to their capability of providing the design requirements and controlling failures associated with leakage, alignment and vibration. Discussions concentrated on the PSOV interfaces with the turbopump, tank, and reactor control systems. Planned instrumentation and their limitations were 
also covered. Reliability presented four existing FMA's on propellant shutoff valves (covering NRX-EST and XE), and Marshall Space Flight Center data on the major cryogenic valve problems for Design's guidance in generating the detailed designs .

\section{E/STS-2/3 Project's "30\% Design Review Backup Information"} (6 volumes and 51 drawings) was reviewed for Reliability's participation in a meeting with Kaiser Engineering which took place in February, 1967.

\section{Indoctrination and Training}

Failure Mode Analysis seminars were held with the NRO and NTO engineers responsible for the implementation of the NRO Program Directive, $\mathrm{RN}-\mathrm{RD}-\mathrm{S}-1074$, released last quarter. The purpose of these briefings was to establish a standard method of accomplishing the FMA technical requirements. Engineers representing most of the engineering departments contributed thoughts that made these meetings mutually productive. Handouts consisting of sample FMA's, supplemental instructional notes, and a copy of an annotated FMA form were distributed to the participants.

\section{Failure Data Collection}

The scope of failure data collection is being enlarged to encompass the acquisition of all significant data which indicates performance limitations. This approach to failure data acquisition is particularly appropriate to the NERVA program with its limited number of tests. Based upon past testing results, the propulsion system performance limitations will be derived and the reliability of nuclear space propulsion will be predicted. Two methods are being established to facilitate Reliability's acquisition of these data. One method involves coding each inspection document that contains performance limitation information, so that it can be electronically segregated from all 
other documents for rellability analysis. The other method requires the routing of all test documents (component proof to system power) through Reliablity for analysis and extraction of approprlate data for use in Failure Mode Analysis, Design Review and Test Planning. 


\section{QUALITY ENGINEERING}

\section{A. PROCUREMENT \& FABRICATION CONTROL}

The NERVA Procurement Requisitions ( $P R^{\prime} s$ ), Interplant Work Authorizations (IWA's), Advance Quotation Requests (AQR's), Purchase Orders (P.0.'s), and Changes processed by Quality Engineering during the 2nd Quarter CY 67 were:

\begin{tabular}{|c|c|c|c|c|c|c|c|}
\hline Month & PR's & $\begin{array}{l}\text { Change } \\
\text { PR's }^{\prime}\end{array}$ & IWA's & $\begin{array}{l}\text { Change } \\
\text { IWA's } \\
\end{array}$ & $\mathrm{AQR}$ 's & Tota1 & $\begin{array}{l}\text { P.0.'s and } \\
\text { P.0. Changes } \\
\end{array}$ \\
\hline Jan & 161 & 34 & 11 & 5 & 2 & 213 & 52 \\
\hline Feb & 136 & 31 & 9 & 7 & 6 & 189 & 52 \\
\hline Mar & 146 & $\underline{33}$ & 7 & 14 & 3 & 203 & 52 \\
\hline Total & 443 & 98 & 27 & 26 & 12 & 605 & 156 \\
\hline
\end{tabular}

During the 2nd Quarter of $\mathrm{CY} 67$ source acceptance actions have been completed on 31 Purchase Orders at 25 Subcontracts and Suppliers plants. Currently 26 Purchase Orders at 20 Subcontractors and Suppliers plants are under surveillance.

Receiving Inspection performed for NRO by Sacramento Plant Inspection during the 2nd Quarter included NRO-designed products (112 line items) and standard products ( 391 line items). NRO PAD provided surveillance for the inspection operations and approved approximately $90 \%$ of the planning.

NRO Quality Engineering, during this Quarter of CY 67, reviewed 242 Shop Orders, which provided planning for processing and assembly of NERVA hardware at Aerojet Sacramento Plant. Only 19 of these Shop Orders needed to be returned to Fabrication Engineering for planning changes. The monthly totals were as follows: 


$\begin{array}{lrrrr} & \text { Jan } & \text { Feb } & \text { Mar } & \text { 2nd Qtr } \\ \text { Shop Orders Processed } & 53 & 75 & 114 & 242 \\ \text { Shop Orders Returned } & 9 & 7 & 3 & 19 \\ \text { \% Shop Orders Returned } & 17 \% & 9 \% & 3 \% & 8 \%\end{array}$

Considerable progress has been made improving Shop Order planning with respect to controlling their release to Sacramento Plant, and getting the latter to follow the Product Assurance call-outs. NRO Quality Engineering, through close coordination with Sacramento Plant personnel and NRO Fabrication Engineering, has established the rule that processing of NRO hardware is accomplished only to Shop Orders that have been reviewed and signed off by NRO Quality Engineering. Shop Order planning improvements were implemented by NRO Quality Engineering; Product Assurance requirements were added to assure adequate documentation and control of product quality during fabrication and processing at AGC Sacramento Plant.

Significant progress has been made by NRO Quality Engineering to coordinate the efforts of NRO Project Engineering, NRO Fabrication Engineering and Sacramento Plant Quality Control, to develop an organized working system and assure acceptable hardware with adequate documentation. Meetings were held with both NRO Project Engineering and Sacramento Plant Quality Control with respect to (a) Inspection assignment and coverage in accordance with hardware demand; (b) Controlling documentation, assembly buildup and travel log books for NRO Products and Components processed to Engineering-prepared procedures; (c) Coordination between NRO Quality Control and Sacramento Plant Quality Control for handling Product Assurance problems related to XE Assemblies; (d) Procedures for preparing the XECF PVARA for shipment.

NRO Quality Engineering Master Record Card file system, for procurement and fabrication of NRO hardware, has been re-organized with respect to indexing, pre-production control plans and procedures, special processes and specific instructions to assure that significant quality control requirements are implemented as early as possible in the pre-planning stages for 
procurement and fabrication of NRO hardware. The system will provide ready reference for historical data of like hardware, for identifying applicable Shop Orders, Purchase Orders and IWA's to which documentation may be filed. The system will materially affect the efficiency of Product Assurance review of Procurement or Fabrication authorizations.

A system of coding the basic elements involved in Inspection Reports will also provide information useful to Product Assurance in review of Shop Orders, Purchase Orders and IWA's for similar types of products and processes. Trends determined through the coding of nonconformance reports as to defect types, causes, and responsibilities will be particularily effective in pre-planning the prevention of discrepancies. This will assure a more organized approach towards effective corrective action. In this regard it was noted that Marquardt Corporation, Ogden, Utah, supplying NERVA Pressure Vessels and U-tube Channels for the NERVA Nozzles, was running into a trend of discrepancies attributed to personnel error. This was brought to the attention of Marquardt management who responded by making an extensive search into underlying causes to fully determine the adequacy of their planning and tooling and found that the reported non-conformances were in fact, operatorcontrollable defects. In addition, Marquardt's management reviewed the nonconformances with their Fabrication and Quality Control personnel in order to emphasize the importance of defect-prevention.

\section{B. NERVA QUALITY ENGINEERING}

The second revision of AGC-STD-9012 (NRO) "Wiring, Routing and Termination of" was rewritten to incorporate valuable comments resulting from a review of Issue 1 and 2 by SNPO-C, NTO, NRO, AGN, and VKC personnel. Sections on printed circuits, and micro-welding were expanded at the request of SNPO-C, Issue 3 should be available for distribution during early April. At the request of SNPO-C this document is intended to be used as the NERVA Program workmanship criteria for all electrical and electronic assemblies 
used for test engines and associated controls. Workmanship requirements based upon the impending issue of AGC-STD 9012 have been incorporated into fabrication orders for all add-on modifications approved for the ETS-1 TSCS and Engine Control Systems. This has been designed to reduce anomalies and improve the functional reliability of these components. It was agreed between SNPO-C, NRO-PAD and NRO Systems Engineering that brazed joints on all engine transducer impulse lines would be $x$-rayed to assure that excessive braze material would not reduce effective cross section of these lines or produce an orifice reaction during engine test use.

A standard modification procedure for rework or modification of printed circuit cards was prepared and coordinated with NRO, WANL, NTO and SNPO-C prior to issue. Such a procedure will permit incorporation of systems modifications at minimum cost and time when such modifications involve changes in electronic circuits. Since this subject is not covered in any Military or NASA Specification it will be submitted as a NASA Technology Utilization Report prior to being issued as an AGC-NRO Specification. This specification is currently being prepared and will be issued in April.

Product Assurance developed the assembly planning with integrated inspection requirements for the TSA, XECF-UTSM, and XE-1 UTSM. As the electrical and instrumentation installation is the last operation in the assembly of the XECF and XE-1 System Modules, the checkout of cables, conductors and transducers, the preparation of data books and end item reports cannot be initiated until the assembly is finished.

The functional analysis and reliability studies on NERVA instrumentation continued throughout the quarter. Since NRX-A6 engine test was not conducted during the quarter, results of evaluation tests on flush mount transducers has not become available. A special capsule has been designed to evaluate thermal gradients within the body of functioning pressure transducers when exposed to a radiation field produced by a linear accelerator. 
Pressure Vesse1 S/N 880013, XE-2 is currently stored at AGC awaiting scheduled shipment to WANL. Source approval was made by NRO-PAD personnel after a source-acceptance trip to the Marquardt Corporation, Ogden, Utah in January 1967.

Blockage of 10 coolant tubes occurred in Nozzle S/N 880028 while processing at Hydro-Lab during February. Obstructions were found to be sections of foreign " 0 " ring seal from the Hydro-test system. To date, 3 tubes have been cleared; the remaining obstructions are being soaked with Xylene (a solvent) to aid in clearing the balance of tubes by pressure flushing. All stoppages are on the convergent side of the throat area. Hydro-test Instruction \#R00093 which controls this processing stage has been revised to positively prevent recurrence of this circumstance - reference revision " $A$ ".

Nozzle S/N 880025, P/N 707630-29R is scheduled for back-up usage on NRX-A6 and prime usage on NRX-A7. This nozzle is completed and in storage at AGC awaiting WANL decision on 3 ICD dimensional deviations. Request for approval/acceptance of deviations has been made through NRO Program Manager.

With respect to the 4 in. Butterfly Valve and Actuator Assembly (TPCV) P/N 1116909-9D, the acceptance testing of S/N 8800023 was performed in two phases. The acceptance test plan was revised to be consistent with end use for $\mathrm{XE}-1$, and a new test plan has been written for $\mathrm{S} / \mathrm{N} 8800024$ to be consistent with XECF application. As to the 4 in. Butterfly Valve and Actuator (TBV) $\mathrm{P} / \mathrm{N}$ 1117188-19, the acceptance documentation for S/N 8800025 has recently been submitted for approval by EIRB. The demonstration test plan was revised based on test findings. All requirements in the acceptance test plan were satisfactorily achieved on S/N 880026 and acceptance documentation is awaiting EIRB approval. Documentation for data books is in process of preparation for EIRB presentation of S/N's 880027 and 880028, as both valves have satisfactorily fulfilled all acceptance criteria requirements. 
Actuator, Bendix P/N 2775030 (AGC P/N 1117876-9), S/N 015, was acceptance tested per revised test plan (RN-TP-0041) and all test objectives were satisfactorily met.

Testing has been completed on five cryogenic $3 / 8$ in. Check Valves, $\mathrm{P} / \mathrm{N}$ 1114730-29, i.e., S/N's 880001 through 880004 and S/N 880009 (Demonstration Valve).

The demonstration tests performed on $3 / 8$ in. Check Valves, P/N 1114730-59 (Elevated Temperature), S/N 880009 and 880006, showed that the design was capable of meeting the specified criteria. Acceptance testing indicated a satisfactory cracking pressure with a pressure differential margin of approximately 2 .

Acceptance testing of the $3 / 8$ in. Control Valves (Marotta $P / N$ 806235) has been completed. S/N's 102 through 106 and the two demonstration valves, S/N 113 and 115, were submitted to and approved by EIRB. S/N's 109 through 112, 118 and 127 had response times which exceeded the acceptance criteria and their usage will be limited to other than turbine block valve. Documentation on the remaining valves is being assembled for presentation.

The new ultrasonic specification AGC STD 9014 (NRO) has been approved this quarter and is to be incorporated on all future drawings.

Final check-out by PAD personnel of the new Eddy Current Rod \& Tube Tester was completed in March at the vendors plant in Newport Beach, California. The unit will be shipped to Sacramento in April, for use in checking bar stock and tubing.

Surveillance by PAD personnel of vendor-supplied $x$-rays at recelving inspection has resulted in several opportunities to help inspection where films are in need of radiographic improvement. In several instances NDT Engineering has assisted inspection by providing scanning densitometry for more accurate interpretation of film. 
Review of nondestructive testing on pressure vessels in the test area has been maintained. VA-11 has been radiographed and the film is now being reviewed. Radiography, performed by a field service contractor, has not been entirely satisfactory. Hence, a number of films are to be repeated. To date one rejectable condition has been found. Magnetic Particle Inspection of VA-11 revealed the manufacturer's weld repair areas and showed one weld defect. U1trasonic contact testing was used to assure absence of gross discontinuities in the weld repairs. VE- 6 has also been radiographed with Cobalt 60 for weld soundness on Nozzles 1 and 2 . One repairable defect has been detected.

Radiography of welding on the Thrust Ring of the C-1 Test Stand at NTO was reviewed. NTO Quality Control reporting of the x-ray defects was confirmed and supported. NDT Engineering input was supplied for rework planning.

The PVARA assembly was approved for shipment subject to subsequent EIR/MRB action at NTO. During the disassembly of the PVARA for shipment, it was observed that the twelve (12) nozzle support tabs were bent at about a $45^{\circ}$ angle. These tab interface to the reactor and provide support to an aluminum seal between the inner and outer reflector of the reactor. Small indentations were noted on the seal where contact had been made. These discrepancies, which were documented on Inspection Reports for both the Nozzle Assembly and the Pressure Vessel Assembly, were preliminarily attributed to a lack of adequate travel of the aluminum reactor seal, resulting from the design. A stack-up study by WANL indicates that 0.1 inches of axial movement should be left in the aluminum cylinder after installation. The actual movement as it presently exists is unknown. Furthermore, there was no deformation of the NRX A-1 Nozzle tabs. Data from the CFDTS tests were reviewed and showed the pressure vessel wall remained at higher temperatures than the aluminum cylinder area in all cases. The opposite temperature conditions would be required to introduce adverse differential growths that 
would lead to deformation of the Nozzle tabs. It was therefore concluded that the Nozzle tab deformation resulted from inadequate travel of the aluminum cylinder during CFDTS Assembly. It is planned that the nozzle with the tabs in their present condition be reinstalled into the PVARA at E-MAD. There the assembly configuration can be viewed to determine if the aluminum barrel covers the flow outlet ports on the nozzle assembly. If it is determined by boroscope inspection that the ports are clear the PVARA will be acceptable for $\mathrm{XECF}$ test usage. If the ports are covered by the aluminum barrel further MRB consideration will be required.

The final assembly of the XECF Upper Module Assembly and the TSA is nearing completion. Inspection records and related documentation is being brought current with fabrication to permit expeditious review by EIRB prior . to shipment.

The new bellows, required for replacement in seven (7) of the TSA lines, successfully passed qualification and acceptance testing at Fairchild Precision Metal, E1 Cajon, California and will be available for replacement in early April.

Subsequent to the shipment of some lines for the lower module to NTO, a condition was noted on the interior of some of the stainless steel lines. It appeared as a brownish discoloration in the heat affected zone adjacent to the welds. All suspect lines in XECF, Test Stand Adapter, XECF Upper Module Assembly, XE Assembly and those not assembled were inspected. The condition is attributed to an oxide formed during welding without adequate inert gas back up. It can be removed by wire brushing without degradation to the part. All lines with this condition at Sacramento will be reworked. NTO has been alerted to this situation.

Acceptance testing of the modified 5000 psi pressure vessels VE-6 and VH-74 was completed during this report period. Both vessels successfully passed a magnetic particle inspection of all interfor welds. 
The interiors were sand blasted, cleaned, and corrosion inhibitor was applied in accordance with specifications and approved procedures. In the succeeding phase of cycling with nitrogen at 5000 psi and 1000 psi, VH-74 showed no leakage (and is therefore acceptable for use), but VE-6 showed some leakage through the gasketed plug seals of both No. 1 and No.2 nozzles (the small plug designs which still contained some of the original sub-standard nozzle welding). A decision was made to remove the old weld material in these two nozzles and to convert them to the large plug configurations which have been successfully tested in the other four nozzles of the two vessels. This work will be conducted in the near future.

Control of the manway closures has been improved by the procurement of a Norbar Torque Multiplier wrench. This makes it possible to measure the torquing closure of the 3-inch manway bolts to a level of $12,500 \mathrm{ft} 1 \mathrm{~b}$. The specified value is $10,500 \pm 500 \mathrm{ft} 1 \mathrm{~b}$. Previously, sledging, with turnof-nut control, was the only method of controlling bolt closures in this high torque range.

Final acceptance testing and approval of the Cryogenic Engineering Co. calibration cryostat was accomplished during this report period. This cryostat was designed for simultaneous comparison of twelve resistance temperature transducers to two NBS traceable calibrated platinum resistance thermometers. Earlier tests, cited in the report for July - September 1966, had revealed design problems which resulted in failure to meet the precise temperature control specifications. The design was changed, from operation with the calibration block under vacuum, to operation in a cryogenic gas environment of approximately one atmosphere. To accomplish this, it was necessary to surround the block with a close-fitting cryogenic-gas chamber resistant to the surrounding vacuum, and to provide proper connections and seals for the cryogenic gas atmosphere. The design changes were coordinated with Aerojet, and the necessary fabrication was accomplished by Cryogenic Engineering. The unit was received at Aerojet and acceptance tested in the Transducer Laboratory and found acceptable in accordance with the requirements 
of AGC Specification 9270:5383, including: (a) the specified system accuracy of $\pm 0.028^{\circ} \mathrm{F}$ at cryogenic temperatures, (b) copper block gradients of $\pm 0.02^{\circ} \mathrm{F}$, (c) temperature stability of $\pm 0.02^{\circ} \mathrm{F}$ for 30 minutes, (d) adjustability of $\pm 2.0^{\circ} \mathrm{F}$, and (e) calibration temperature range of -425 to $-297^{\circ} \mathrm{F}$. The cooldown time and liquid helium boiloff rates were not fully within specifications, but are within acceptable operating limits and do not compromise the actual performance of the cryostat.

Acceptance testing and delivery of a new type (Self-Y-Conduit) ambient temperature, 2500 psi ASA, 8 inch C.S. valve by Controls Components, Inc., was accomplished during this period. In initiating testing at the vendor's shop, it was discovered that the valve wearing parts had been chrome plated, but that dye penetrant or magnetic particle inspection of the valve body, and radiographic inspection of the valve spindle had been omitted. The discrepancy was attributed to inadequate communications within the supplier's organization. Through SDAR 30539 the requirement for dye penetrant inspection was removed because of the chrome plating. The valve was disassembled, subjected to the magnetic particle and radiographic inspection, and found satisfactory. Upon reassembly it passed all functional and proof tests. 
IV. QUALITY ASSURANCE - NRO

A. SYSTEMS AND PROCEDURES

The following quality and reliability procedures, unique to the NRO organization at Sacramento, were issued during this quarter:

\section{New Procedures}

QP 12-1-21 Documentation Contro1 - NRO PAD

This procedure defines the flow of the basic quality documentation (such as purchase orders, shop orders, assembly procedures, etc.) from the point where NRO Quality Engineering defines the quality requirements to the point where the basic documentation, properly stamped-off by inspection, is placed in permanent storage.

QP 15-1-21 Nonconforming Materia1 Contro1 - NRO

This procedure states that NRO uses the same procedure for controlling nonconforming material as is defined in the Sacramento Plant QC procedure, with the exception of five modifications which affect only the operation of a limited group of NRO personnel.

QP 15-1-22 Preparation of the Inspection Report (IR) - NRO Here again, NRO uses the Sacramento Plant QC procedure, with the exception of two minor modifications affecting only a small number of NRO personne1.

\section{QP 15-1-23 Corrective Action System - NRO}

This procedure defines the NRO system for assuring that effective corrective action is taken on all significant reported discrepancies. The NRO system is significantly different from the system defined in Sacramento Plant QC procedures. 


\section{Revisions}

QP 12-2-21a End Item Reports - NRO

This procedure defines the general content, format, use, and procedural responstbilities concerning end item reports (EIR's). The revision greatly simplified the old procedure, and changed a number of organizational responsibilities.

QP 12-2-22a Quality Assurance Data Books - NRO

This procedure defines the general content, format, use, and procedural responsibilities concerning data books. Here again, the revision simplified the old procedure and changed certain requirements.

\section{Cancellations}

QP 5-1-22 Planning at Station 640

This procedure was cancelled because the Manufacturing Shop effort was reorganized completely eliminating Station 640. All shop planning (including the necessary inspection planning) for NRO material is completely defined in the existing QP 11-1-21, dated 30 July 1965.

All proposed Sacramento Plant publications having a direct bearing on NRO PAD were reviewed for compliance with the requirements of Reliability and Quality Assurance Program Plan No. 2469, Revision C. These publications included Standard Practice Instructions, Sacramento Plant Quality Control Instructions and Quality Procedures, and NRO Project Directives. 
B. DATA AND DOCUMENTATION

Documents prepared during this quarter for data books and end item reports reflected a two-fold increase over the previous quarter and covered the following items:

\section{Data Books}

a. Lines

Middle Turbine Inlet
Inlet PIL
Pneumatic Supply
Purge
TPCV Supply
Pneumatic Vent
Shield Fill
Shield Vent
Diluent
Line Segment
Turbine Exhaust
Turbine Inlet
Line Segment Vent
Cooldown

$\mathrm{S} / \mathrm{N} 1,2$

$\mathrm{S} / \mathrm{N} 2$

$\mathrm{S} / \mathrm{N} 1,2$

$\mathrm{S} / \mathrm{N} 2$

$\mathrm{S} / \mathrm{N} 1$

$\mathrm{S} / \mathrm{N} 2$

$\mathrm{S} / \mathrm{N} 1$

$S / N 1$

$\mathrm{S} / \mathrm{N} 0$

$\mathrm{S} / \mathrm{N} 1$

$\mathrm{S} / \mathrm{N} 1,2,3,4$

$\mathrm{S} / \mathrm{N} 1,2,3$

$\mathrm{S} / \mathrm{N} 1$

$\mathrm{S} / \mathrm{N} 1$

b. Valves

$3 / 8$ in. Check

5 in. Butterfly

8 in. Poppet

4 in. Butterfly (with Actuator)
S/N $6,9,3,4,10,11$

$\mathrm{S} / \mathrm{N} 4$

S/N 102

S/N 27, 28, 24 
c. Miscellaneous

$\begin{array}{ll}\begin{array}{l}\text { PVARA less Hot Gas Port } \\ \text { (Supplement) }\end{array} & \mathrm{S} / \mathrm{N} \text { (none) } \\ \text { Manifold } & \mathrm{S} / \mathrm{N} 1 \\ \text { Exhaust Manifold } & \mathrm{S} / \mathrm{N} 1 \\ \text { Remote Nut Assembly } & \mathrm{S} / \mathrm{N} 1 \text { through } 30 \\ \text { Hot Gas Port } & \mathrm{S} / \mathrm{N} 88 \\ \text { Lower Thrust Structure } & \mathrm{S} / \mathrm{N} 13,14 \\ \text { Upper Thrust Structure } & \mathrm{S} / \mathrm{N} 12 \\ \text { Line Assy. Housing, Dr. Shft. } & \mathrm{S} / \mathrm{N} 1 \text { through } 30 \\ \text { External Shield } & \mathrm{S} / \mathrm{N} 101 \\ \text { Pedestal Assembly } & \mathrm{S} / \mathrm{N} 1 \text { through } 12 \\ \text { Temperature Transmitter } & \mathrm{S} / \mathrm{N} 3 \text { through } 25 \\ \text { Motor Chain Drive } & \mathrm{S} / \mathrm{N} 1 \\ \text { Nozzle } & \mathrm{S} / \mathrm{N} 25 \\ \text { Actuator (Bendix) } & \mathrm{S} / \mathrm{N} 15 \\ \text { TPA Refurbishment } & \mathrm{S} / \mathrm{N} 16\end{array}$

\section{End Item Reports}

a. Valves

5 in. Butterfly

$\mathrm{S} / \mathrm{N} 5$

$3 / 8$ in. Check

$\mathrm{S} / \mathrm{N} 1,2$

b. Lines

Inlet PIL

Middle Turbine Inlet

Turbine Inlet Elbow

Turbine Inlet
$\mathrm{S} / \mathrm{N} 2$

$\mathrm{S} / \mathrm{N} 1,2$

$\mathrm{S} / \mathrm{N} 1$

$\mathrm{S} / \mathrm{N} 1$ 
c. Filters
1 in. Filter
S/N 3 through 8
2 in. Filter
S/N 1 through 3

d. Miscellaneous

TPA (Refurbished)

$\mathrm{S} / \mathrm{N} 16$

5 in. Adapter

$\mathrm{S} / \mathrm{N} 3,4$

Exhaust Manifold

$\mathrm{S} / \mathrm{N} 1$

Manifold

$\mathrm{S} / \mathrm{N} 1$

Line Assy. Housing Dr. Shaft

$\mathrm{S} / \mathrm{N} 1,5,12,13,14,16$, $18,21,23,27,28,29$

PVARA less Nozzle and Hot Gas Port

$\mathrm{S} / \mathrm{N}$ (none)

Nozzle and Hot Gas Port

S/N 23 and 88 respectively

Lower Thrust Structure

$\mathrm{S} / \mathrm{N} 13$

External Shield

$S / N 101$ 
C. STATISTICAL DATA (NERVA HARDWARE)

\section{Receiving Inspection}

\begin{tabular}{lcccc} 
& \multicolumn{5}{c}{ SUMMARY } \\
Parts Received & January & February & March & $\frac{\text { Quarter }}{2}$ \\
Parts Discrepant & 6492 & 417 & 347 & 7256 \\
Discrepant Characteristics & 28 & 201 & 11 & 240 \\
Defects per part (c) & 47 & 206 & 22 & 275 \\
Percent discrepant (P) & 0.007 & 0.495 & 0.064 & 0.038
\end{tabular}

Note: P/N 1117511 - Bolt: 200 of the 206 discrepancies in February were the result of Qualification Test Results not being available at the time of Receiving.

DISCREPANCIES AT RECEIVING

\begin{tabular}{|c|c|c|c|c|c|}
\hline Cause & & January & February & March & Quarter \\
\hline Operator & & 8.2 & 10.8 & 3.7 & $8.6 \%$ \\
\hline Design & & - & - & - & - \\
\hline Tooling/Gaging & & 10.5 & 5.0 & 45.7 & $14.6 \%$ \\
\hline Parent Material & & - & - & 9.4 & $1.8 \%$ \\
\hline Planning & & 10.0 & 3.2 & 1.0 & $4.9 \%$ \\
\hline Inspection & & 48.5 & 73.8 & 5.6 & $52.8 \%$ \\
\hline Special Process/Test & & 1.2 & 5.0 & 9.4 & $4.7 \%$ \\
\hline Unknown & & 21.6 & 2.2 & 25.2 & $12.6 \%$ \\
\hline & TOTALS & $100.0 \%$ & $100.0 \%$ & $100.0 \%$ & $100.0 \%$ \\
\hline
\end{tabular}




\section{AGC Processing Summary}

Discrepancies Include:

a. Number of $P / N^{\prime} s$

b. Number of Shop Orders

c. Number of IR's

d. Total Pieces

e. Total Characteristics

\section{Disposition of Discrepant Pieces:}

a. Accept-as-is

63

b. Rework or Repair

c. Reject

Disposition of Discrep. Characteristics: 39

42

48

158

248

84

11
136

100

12
January

a. Accept-as-is

b. Rework or Repair

c. Reject

Discrepancies Include:

a. Number of $P / N^{\prime} s$

b. Number of Shop Orders

c. Number of IR's

d. Total Pieces

e. Total Characteristics
Fabrication (Machining)

February March Quarter

21

12

72

22

13

77

30

22

100

49

26

233

114

50

412

104

115

14

15

2

$28 \quad 244$

$18 \quad 151$

4

17

\section{Assemb ly}

$\begin{array}{rrrr}33 & 25 & 33 & 91 \\ 17 & 20 & 12 & 49 \\ 44 & 33 & 51 & 128 \\ 67 & 55 & 73 & 195 \\ 110 & 91 & 129 & 330\end{array}$


Disposition of Discrepant Pieces:

January February March Quarter

a. Accept-as-1s

b. Rework or Repair

c. Reject

Disposition of Discrep. Characteristics:
a. Accept-as-is
b. Rework or Repair
c. Reject

34
11

35

21

TOTAL AEROJET PROCESSING

Discrepancies Include:

a. Number of $P / N^{\prime} s$

72

b. Number of Shop Orders

59

c. Number of IR's

92

d. Total Pieces

e. Total Characteristics

Disposition of Discrepant Pieces:

a. Accept-as-is

74

b. Rework or Repair

119

c. Reject

\begin{tabular}{l}
54 \\
36 \\
\hline
\end{tabular}

83

171

24

225

358

$\begin{array}{rrr}46 & 45 & 163 \\ 42 & 25 & 126 \\ 63 & 73 & 228 \\ 104 & 99 & 428 \\ 205 & 179 & 742\end{array}$

Disposition of Discrep. Characteristics:
a. Accept-as-is
b. Rework or Repair
c. Reject

170

155

33

$\begin{array}{rrr}134 & 111 & 415 \\ 69 & 62 & 286 \\ 2 & 6 & 41\end{array}$

175

215

38

41 
D. QUALITY ASSURANCE TEST AREA

The XE-UTS/Shield Segment Cryogenic Tests were completed successfully on 24 February 1967. The objectives of the testing is summarized as follows:

(1) To determine effects of purge gas condensation on XE engine components, structures and insulation.

(2) Provide a gross leak check of joints.

(3) Determine valve response characteristics under simulated operating environment.

(4) Checkout of UTS TV monitoring system.

All test objectives were met and temperature and pressure data were obtained which will be used for a thermal analysis. 


\section{NTO QUALITY CONTROL}

\section{A. GENERAL}

The Product Assurance Program Plan was revised following a meeting between NTO Product Assurance, NRO and WANL. The plan was retyped and copies were distributed to NRO, WANL, NTO and SNPO for final revlew.

Product Assurance Quality Rellability Instructions were updated in accordance with a planned schedule to rewrite outmoded QRI's and inftiate new ones as required.

Product Assurance representatives visited ACFI, Albuquerque, New Mexico to review anticipated problems associated with the transfer of ACFI test records and inspection data associated with the NRX-A6 actuators when phaseout of ACFI operations is accomplished.

The NTO Product Assurance Manager attended the eighth meeting of the NERVA Cleanliness Committee on February 15 and 16, 1967. Three major items discussed in detail at the meeting were as follows:

(a) Status of cleanliness control at ETS-1

(b) E-MAD cleanliness control areas for assembly of NRX-A6 and XE

(c) Status of sampling and acceptance procedures for propellants and gases delivered to NTO.

\section{B. MAD OPERATIONS}

MAD Operations continued activities at E-MAD during this period, having completed the move from R-MAD. Product Assurance personnel contacted cognizant E-MAD Operating Groups to establish necessary operating procedures. 
Continued surveillance was provided for the NRX-A6/T7 Test Car build-up. Product Assurance procedures and inspection instructions were prepared as necessary to provide adequate information to Product Assurance inspectors.

NTO procedures governing XECF, NRX-A6 and XE-1 were reviewed by Product Assurance personnel.

Cleanliness specifications covering air sampling and measurement of particle size, and approval of the Pan Am facility were initiated by Product Assurance.

Drawings covering E-MAD facilities and Test Car associated hardware were reviewed by Product Assurance.

Welder certification at E-MAD was initiated, as well as a welding procedure.

Surveillance of the calibration of E-MAD testing equipment was performed and necessary action taken to obtain compliance of requirements.

\section{TEST CELL "C" OPERATIONS}

Product Assurance reviewed vendor fabrication packages for test cell modification work.

A Program Plan for Test Cell "C" was prepared and circulated for review by Product Assurance.

Product Assurance maintained a discrepancy $\log$ for Phoebus IB tests and prepared a test summary for distribution. 
The test discrepancy synopsis for Phoebus Experimental Plans 1 through 6 was prepared for LASL dissemination.

Several audits were performed on EG\&G activities in Test Cell "C", resulting in several changes in EG\&G's method of operations.

\section{ETS-1 OPERATIONS}

During this quarter NTO Product Assurance monitored the repair of the V 5001 inlet lines, the repair of a bellows section of the outlet line, and the wipe test performed on the run tank for conformance to NERVA Cleanliness Standards.

An ETS-1 discrepancy log procedure has been instituted as of the latter part of this reporting period. In essence, the procedure requires a quality control engineer to be in, or in proximity to, the control room. The standard operating procedure will require the initiation of discrepancy reports by NTO personnel, and control and review of the initiated documents by NTO Product Assurance.

A revised Engineering Change Control Procedure has been initiated and the attendant inspection operations with the Support Services Contractor, EG\&G, have been initially defined. The revised ECR procedure provides for a reduction in the amount of documentation generated by the Support Services Contractor to document conditions of noncompliance.

An audit of the Pan Am Valve Shop was performed during the latter part of the quarter, and the results of the audit will be transmitted to the necessary personnel for action. 
NTO Product Assurance personnel have been closely involved with the weld repair requirements on the test stand thrust ring. Support Services Contract welders are currently being certified in accordance with NTO standards.

Engine test compartment quality control functions were assumed by NTO Product Assurance during the latter part of the quarter. The NTO personnel assigned to the engine test compartment have been designated as members of the task force subsequent to beneficial occupancy date (BOD).

The final buy off on the duct instrumentation is to be effected upon a review of the final instrumentation checkout data. The final buy off has been delayed because of facility experimental plan requirements.

\section{E. RELIABILITY}

Product Assurance personnel surveyed activity on the System Print for Electrical Power Distribution, and instituted coordination with Site Engineering Group on controls requirements for various functional requirements for the A-6 series.

Work was completed on the system prints for Test Ce11 "C" Turbine Energy Source, Hot Water System, and the $\mathrm{LN}_{2}$ Reference Dewar.

Coordination activities with WANL/Large included a clarification of the electrical and mechanical problems on the SEG-FR-DC-139, "Side-by-Side Pressure Transducer Experiment", and participation in the planning and scheduling of the NRX-A6 Failure Mode Analysis. 